\title{
DESCRIPTION OF A NEW GENUS OF PHYLLOSTOME BATS.
}

\author{
BY
}

Harrison Allen, M. D.

Mr. Frederick W. True, curator of the department of mammals, National Museum, has placed in my hands a skin in spirits of a small leafnose bat, believed to be from the vicinity of the Segovia River, Eastern Honduras. The specimen had been eviscerated and the skull removed. The lower lip was badly mutilated. From the characters furnished by the nose-leaf and the peculiar coloration of the fur, I believe the form to be a new genus allied to Stenoderma, and describe it as follows:

\section{Ectophylla, new genus.}

Nose-leaf erect, basal part notched in middle of free margin. Nostrils entire (but grooved continuous to outer margin of nose-leaf) separated by a small rounded nodule which apparently represents the lower part of the median leaf-crest, which otherwise is absent. Lateral glandclumps rudimental, borne on the surface of a flat, scalloped skin-fold. Auricle as in Hemiderma, simple, erect, ovate; as measured from the crown it is shorter than the head. The single scallop begins abruptly at the middle of the moderately convex outer border. The external basal lobe convex and slightly thickened; basal ridge, or lappet, none. The internal basal lobe is rounded and free. Tragus almost one-half the height of the auricle, moderately convex on the inner margin, irregularly convex on outer, and furnished with two coarse serrations near the base. Lower lip mutilated. The mentum shows signs of having borne a row of eight (?) marginal rounded warts, and a small median one placed behind them. The lip apparently not cleft. Wings as in subfamily. Interfemoral membrane consists of a broad hem to the inferior extremity and pubis. Tail absent; tip of calcar projecting. The wing membrane reaches a point nearly midway between the ankle and the base of the metatarsi. The first phalanges shorter than the second. The first phalanx of the third finger about one-third the length of the corresponding metacarpal bone. The fifth metacarpal bone as long as the forearm. The phalanx of the second digit $3 \frac{1}{2}$ millimeters long, and equals about one-fourth the length of the corresponding metacarpal bone. 
Ectophylla alba, new species.

Characters of the single species that of the genus. Above, the hair is of a dull whitish hue, and unicolored to the level of the shoulder. Through the rest of the back the hair is of a duller shade of white, except the tip, which is fawn. Below, the coloration is much the same as above, but the sides of the trunk, from the shoulders to the rump, are unicolored dark fawn, while the median part is whiter. Owing to the humeri being broken and the wing membranes distorted, it is

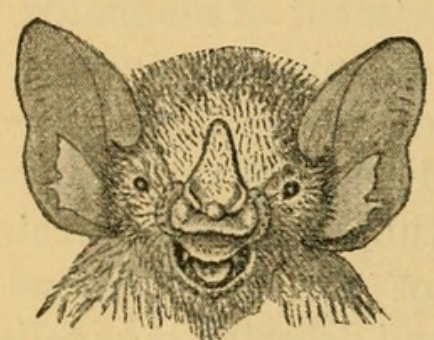

Fig. 1. Front view of head of Ectophylla alba; $1 \frac{1}{2}$ times natural size.

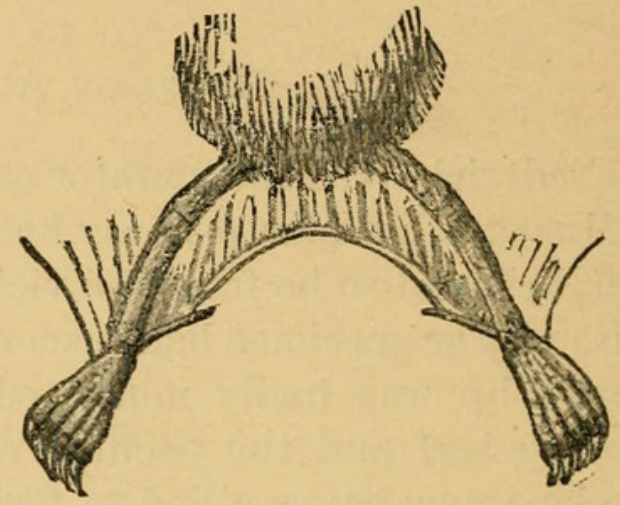

Fig. 2. Dorsal view of the inferior ex tremities and interfemoral membrane of Eetophylla alba; $1 \frac{1}{2}$ times natural size.

difficult to determine the exact distribution of the hair on the membrane. Below, unicolored dark fawn hair appears to extend outward as far as the elbow. The interfemoral membrane is naked.

Measurements.

Millimeters.

Head and body (from erown of head

to base of tail) ............... 36

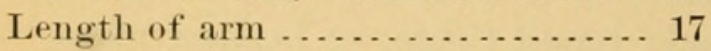

Length of forearm ............ 25

First digit :

Length of first metacarpal bone. 3

Length of first phalanx ........ 3

Second digit:

Length of second metacarpal bone .................. 21

Length of first phalanx ....... $3 \frac{1}{9}$ Third digit:

Length of third metacarpal bone. 25 Length of first phalanx ........ 9 Length of second phalanx ..... 12 Length of third phalanx ...... 6
Fourth digit:

Millimeters.

Length of fourth metacarpal bone 25

Length of first phalanx....... $7 \frac{7}{2}$

Length of second phalanx ..... 8 Fifth digit:

Length of fifth metacarpal bone. 25

Length of first phalanx $\ldots . . .66$

Length of second phalanx ..... 7

Length of head ............... 14

Height of ear ................ 10

Height of tragus . . . . . . . . . . . $5 \frac{1}{2}$

Length of thigh............... $8 \frac{1}{2}$

Length of tibia ............... 10

Length of foot ............... 8

Width of interfemoral membrane

from middle of rump ........... 4 


\section{$2 \mathrm{BHL}$ Biodiversity Heritage Library}

Allen, Harrison. 1892. "Description of a new genus of phyllostome bats." Proceedings of the United States National Museum 15(913), 441-442. https://doi.org/10.5479/si.00963801.15-913.441.

View This Item Online: https://www.biodiversitylibrary.org/item/53607

DOI: https://doi.org/10.5479/si.00963801.15-913.441

Permalink: https://www.biodiversitylibrary.org/partpdf/52702

\section{Holding Institution}

Smithsonian Libraries

\section{Sponsored by}

Smithsonian

\section{Copyright \& Reuse}

Copyright Status: Public domain. The BHL considers that this work is no longer under copyright protection.

This document was created from content at the Biodiversity Heritage Library, the world's largest open access digital library for biodiversity literature and archives. Visit BHL at https://www.biodiversitylibrary.org. 